\title{
Pharmacological Profile of the Bradycardic Agent Ivabradine on Human Cardiac Ion Channels
}

\author{
Nicholas Haechl Janine Ebner Karlheinz Hilber Hannes Todt Xaver Koenig \\ Department of Neurophysiology and Neuropharmacology, Center for Physiology and Pharmacology, \\ Medical University of Vienna, Vienna, Austria
}

\section{Key Words}

Ivabradine • S16257 • Human • Cardiac ion channels • Induced pluripotent stem cells

\begin{abstract}
Background/Aims: Ivabradine lowers the heart rate by inhibition of hyperpolarisationactivated cyclic nucleotide-gated ( $\mathrm{HCN}$ ) channels mediating the 'funny' pacemaker current $I_{f}$ in the sinoatrial node. It is clinically approved for the treatment of heart failure and angina pectoris. Due to its proposed high selectivity for $\mathrm{I}_{\mathrm{f}}$ administration of ivabradine is not associated with the side effects commonly observed following the application of other heart rate lowering agents. Recent evidence, however, has shown significant affinity of ivabradine towards $\mathrm{K}_{v} 11.1$ (ether-a-go-go related gene, ERG) potassium channels. Despite the inhibition of $K_{v}^{v} 11.1$ channels by ivabradine, cardiac action potential (AP) duration and heart rate corrected QT interval $\left(\mathrm{QT}_{\mathrm{c}}\right)$ of the human electrocardiogram (ECG) were not prolonged. We thus surmised that compensatory mechanisms might counteract the drug's inhibitory action on $\mathrm{K}_{\mathrm{v}} 11.1$. Methods: The effects of ivabradine on human $\mathrm{K}_{v} 11.1$ and $\mathrm{K}_{\mathrm{v}} 7.1$ potassium, $\mathrm{Ca}_{\mathrm{v}} 1.2$ calcium, and $\mathrm{Na}_{v} 1.5$ sodium channels, heterologously expressed in tsA-201 cells, were studied in the voltage-clamp mode of the whole cell patch clamp technique. In addition, changes in action potential parameters of human induced pluripotent stem cell (iPSC) derived cardiomyocytes upon application of ivabradine were studied with current-clamp experiments. Results: Here we show that ivabradine exhibits significant affinity towards cardiac ion channels other than $\mathrm{HCN}$. We demonstrate for the first time inhibition of human voltage-gated $\mathrm{Na}_{\mathrm{v}} 1.5$ sodium channels at therapeutically relevant concentrations. Within this study we also confirm recent findings of human $\mathrm{K}_{v} 11.1$ inhibition by low $\mu \mathrm{M}$ concentrations of ivabradine and observed no prolongation of ventricular-like APs in cardiomyocytes derived from iPSCs. Conclusion: Our results provide an explanation why ivabradine, despite its affinity for $\mathrm{K}_{v} 11.1$ channels, does not prolong the cardiac AP and $\mathrm{QT}_{c}$ interval. Furthermore, our results suggest the inhibition of voltage-gated $\mathrm{Na}_{v} 1.5$ sodium channels to underlie the recent observations of slowed
\end{abstract}

N. Haechl and J. Ebner contributed equally to this work. H. Todt and X. Koenig share the senior authorship.

\begin{tabular}{ll}
\hline Xaver Koenig & Center for Physiology and Pharmacology, Department of Neurophysiology and Neuropharmacology \\
& Medical University of Vienna, Schwarzspanierstrasse 17, 1090 Vienna (Austria) \\
& Tel. +43 14016031232 , E-Mail xaver.koenig@meduniwien.ac.at
\end{tabular}


atrioventricular conduction by increased atrial-His bundle intervals upon administration of ivabradine.

\section{Introduction}

The bradycardic agent ivabradine is clinically approved for the treatment of heart failure (HF) and stable angina pectoris [1, 2]. The heart-rate lowering action of ivabradine was proposed to rely on the inhibition of hyperpolarisation-activated cyclic nucleotidegated (HCN) channels [3-5]. HCN channels are strongly expressed in cells of the sinoatrial (SA) node and mediate the "funny" pacemaker current If. Inhibition of these channels slows diastolic depolarization and delays the generation of subsequent action potentials (APs).

In contrast to conventional treatment with beta blockers and calcium channel inhibitors, the administration of ivabradine is not associated with hypotension and negative inotropic side effects $[1,6,7]$. This is attributed to the drug's high selectivity towards HCN channels. Consequently, the drug exhibits a good overall cardiac safety profile $[8,9]$. In particular, application of ivabradine induced only negligible if any prolongation of the cardiac AP in various animal models [9-11] and did not alter the heart rate corrected QT interval (QT) of the human ECG [12]. Nevertheless, ivabradine was added to the list of drugs with an inherent risk for torsade-de-pointes (TdP) arrhythmias when combined with QT interval prolonging drugs, diuretics, or in the context of altered electrolyte levels [8]. Recently it was noted that ivabradine has the propensity to inhibit the rapid delayed rectifying potassium $\left(\mathrm{K}^{+}\right)$current $\mathrm{IK}_{\mathrm{r}}$ both in rabbit ventricular cardiomyocytes [10] and when respective $\mathrm{K}_{\mathrm{v}} 11.1$ channels were studied in a heterologous expression system $[9,13]$. The obtained $\mathrm{IC}_{50}$ values for current inhibition were comparable to the concentration range responsible for the action of ivabradine on HCN channels. Thus, ivabradine exhibits significant affinity towards $\mathrm{K}_{\mathrm{v}} 11.1$ (ether-a-go-go-related gene channel, ERG) channels [8, 9,13], but does not per se prolong the cardiac AP $[10,11])$.

Such failure of a drug to prolong the AP despite potent block of $\mathrm{K}_{\mathrm{v}} 11.1$ could result from simultaneous compensatory interaction with other ion channels. Thus, multichannel blockers such as amiodarone, ranolazine and verapamil rarely cause TdP arrhythmias despite blocking $\mathrm{K}_{\mathrm{v}} 11.1$ channels [14]. This prompted us to hypothesise that a compensatory mechanism could counteract the expected AP prolonging effect of $\mathrm{K}_{\mathrm{v}} 11.1$ channel inhibition by ivabradine. One possibility to counteract $\mathrm{K}_{\mathrm{v}} 11.1$ inhibition could be a potentiation of $\mathrm{K}_{\mathrm{v}} 7.1$ channels, which mediate the $\mathrm{K}^{+}$current $\mathrm{IK}_{\mathrm{s}}^{\mathrm{v}}$. The effect of ivabradine on these channels, which provide the second major conductance driving late repolarisation, however, haven't been studied as yet. Notably, apart from the inhibition of $\mathrm{K}_{\mathrm{v}} 11.1$ channels by ivabradine, none of the mentioned evidence was derived from human tissue or human channel isoforms. Inhibition of voltage-gated sodium $\left(\mathrm{Na}^{+}\right)$and/or calcium $\left(\mathrm{Ca}^{2+}\right)$ channels represents another potential compensatory mechanism, which would lead to a shortening of the cardiac AP. Some evidence in this regard has emerged from previous studies on animal models. In cells from rabbit SA node T-type calcium channels were not affected, but L-type calcium channels were inhibited by about $20 \%$ in the presence of $10 \mu \mathrm{M}$ ivabradine [3]. In dog cardiac Purkinje cells and papillary muscle from guinea pig it was noted that maximal AP upstroke velocity $\left(\mathrm{V}_{\max }\right)$ was significantly slowed in the presence of 1 and $10 \mu \mathrm{M}$ ivabradine $[10,11]$, suggesting an inhibition of voltage-gated sodium channels by the drug in these preparations.

The notion that ivabradine may inhibit depolarizing currents is also supported by the finding that AV-nodal conduction is slowed by ivabradine alone [15] or in combination with the sodium channel blocker ranolazine [16].

As a matter of fact there is growing interest in the potential use of ivabradine as a ratecontrolling agent in atrial fibrillation. Hence the exploration of the molecular underpinnings of the effect of ivabradine on AV-nodal conduction may be of substantial clinical relevance [17-21]. Although in silico studies suggest that block of HCN channels per se may result in slowing of AV-nodal conduction [22,23], it has been suggested that this effect of ivabradine 


\section{Cellular Physiology Cell Physiol Biochem 2019;53:36-48

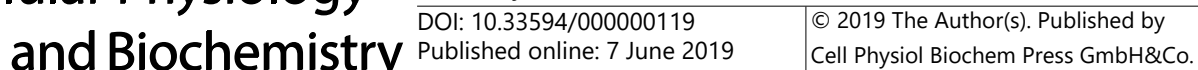 \\ Hächl et al.: Ivabradine Effects on Human Cardiac Ion Channels}

may result from additional block of voltage-gated $\mathrm{Ca}^{2+}$ and/or $\mathrm{K}^{+}$channels [24]. In addition to voltage-gated $\mathrm{Ca}^{2+}$ channels, voltage-gated $\mathrm{Na}^{+}$channels may also contribute to $\mathrm{AV}$-nodal conduction (see below). Therefore, we explored the effect of ivabradine both on voltagegated $\mathrm{Ca}^{2+}$ and on voltage-gated $\mathrm{Na}^{+}$channels.

In summary, both the lack of increase of AP duration by ivabradine despite significant $\mathrm{IK}_{\mathrm{r}}$ blocking properties, and the slowing of AV-nodal conduction could be a result of block of either voltage-gated calcium or sodium channels. Within the present study we therefore investigated the effect of ivabradine on human voltage-gated ion channels responsible for shaping cardiac repolarisation including human $\mathrm{K}_{\mathrm{v}} 11.1$ (hERG), $\mathrm{K}_{\mathrm{v}} 7.1$ (mediating $\mathrm{IK}_{\mathrm{s}}$ current), $\mathrm{Ca}_{\mathrm{v}} 1.2$ (L-type calcium current), and $\mathrm{Na}_{\mathrm{v}} 1.5$. In addition, we studied the effect of ivabradine on APs using cardiomyocytes derived from human induced pluripotent stem cells.

We show that ivabradine exhibits significant affinity towards cardiac ion channels other than HCN. In particular, we demonstrate a pronounced inhibition of human voltage-gated $\mathrm{Na}_{\mathrm{v}} 1.5$ sodium channels in the presence of low $\mu \mathrm{M}$ concentrations of ivabradine.

\section{Materials and Methods}

\section{Cell lines and culturing}

Heterologous expression was performed in tsA-201 cells, a transformed human embryonic kidney 293 (HEK293) cell line expressing an SV40 T-antigen, known for its efficient expression of recombinant proteins. As with HEK293 cells, tsA-201 cells do not express endogenous sodium or calcium currents and only a very small component of outward $\mathrm{K}^{+}$currents at depolarised potentials. tsA-201 cells (American Type Culture Collection, Manassas, VA) were propagated in Dulbecco's modified Eagle's medium (Invitrogen, Vienna, Austria) containing $10 \%$ fetal bovine serum and incubated at $37^{\circ} \mathrm{C}$ in a humidified incubator with $5 \% \mathrm{CO} 2$. Human induced pluripotent stem cell derived cardiomyocytes (hiPS-CM) were purchased from Cellular Dynamics, International (USA), and cultured according to the manufacturer's protocol.

\section{Heterologous transfection}

For expression of human $\mathrm{K}_{\mathrm{v}} 11.1$ (hERG) channels, cells were transfected with pcDNA3 plasmid containing the canonical coding sequence for the human cardiac ERG $\mathrm{K}^{+}$channel $\left(\mathrm{Kcnh} 2, \mathrm{~K}_{\mathrm{v}} 11.1\right.$, UniProt Q12809) (0.7 $\mu \mathrm{g} / 3.5 \mathrm{~cm}$ dish). Co-transfection with pEGFP-C1-plasmid (0.02 $\mu \mathrm{g})$ encoding green fluorescent protein allowed the identification of successfully transfected cells. For expression of $\mathrm{K}_{\mathrm{v}} 7.1$ channels, cells were transfected with pcDNA3 plasmid containing the canonical coding sequence for the human $\mathrm{K}_{\mathrm{v}} 7.1$ (KCNQ1) and the accessory human subunit encoded by human KCNE1 at a 1:1 stoichiometry. For expression of $\mathrm{Ca}_{\mathrm{v}} 1.2$ channels, the pore forming human alpha subunit hCa $1.2 \alpha 1$ (77-pcDNA3) was co-expressed together with the auxiliary subunits cloned from rat, $\mathrm{Ca}_{\mathrm{v}} \beta 3$ and $\mathrm{Ca}_{\mathrm{v}} \alpha 2 \delta 1$, as previously described [25]. For expression of $\mathrm{Na}_{\mathrm{v}} 1.5$ channels, cells were transfected with $1.6 \mu \mathrm{g} / 3.5 \mathrm{~cm}$ dish of pGEM3-plasmid containing the coding sequence for a GFP-tagged human cardiac $\mathrm{Na}_{\mathrm{v}} 1.5$.

\section{Patch Clamp Technique}

Ionic currents were recorded from tsA-201 cells 24-48 hours after transfection at room temperature $\left(22+-2^{\circ} \mathrm{C}\right)$ using an Axoclamp 200B patch-clamp amplifier (Axon Instruments, Union City, CA). Pipettes were formed from aluminosilicate glass (A120-77-10; Science Products, Hofheim, Germany) with a P-97 horizontal puller (Sutter Instruments, Novato, CA) and had resistances between 1 and $2 \mathrm{M} \Omega$ when filled with the respective pipette solutions. Data acquisition was performed with pClamp 11.0 software (Axon Instruments) through a 16-bit A-D/D-A interface (Digidata 1440; Axon Instruments). Data were analysed with Clampfit 10.2 (Axon Instruments) and Prism 5.01 (GraphPad Software, San Diego, CA) software. Rapid solution exchange was performed by a DAD-8-VC superfusion system (ALA Scientific Instruments, Westbury, NY). If not stated otherwise all recordings were obtained in the whole cell configuration of the patch-clamp technique. However, to prevent run-down of $\mathrm{K}_{\mathrm{v}} 7$ currents [26] the perforated patch clamp technique was performed. To this end, glass capillaries were front filled by dipping them into pipette solution for a few seconds. Thereafter the same capillaries were backfilled with the same solution including $200 \mu \mathrm{g} \mathrm{ml} \mathrm{m}^{-1}$ amphotericin B (in 0.8\% DMSO). Currents were recorded after 20-30 minutes when series resistance had 


\section{Cellular Physiology Cell Physiol Biochem 2019;53:36-48 \\ \begin{tabular}{l|l} 
and Biochemistry & $\begin{array}{l}\text { DOl: 10.33594/000000119 } \\
\text { Published online: } 7 \text { June } 2019\end{array}$ \\
\hline
\end{tabular} \\ Hächl et al.: Ivabradine Effects on Human Cardiac Ion Channels}

stabilised below $12 \mathrm{MOhm}$. Action potentials (APs) were recorded from "ventricular-like" hiPS-CM in the current-clamp mode of the whole cell patch clamp technique as in our previous study [27] using both an Axoclamp 200B as well as an Axoclamp 700B amplifier. APs were elicited at $0.5 \mathrm{~Hz}$ by rectangular current pulses of $4 \mathrm{~ms}$ duration at $125 \%$ threshold level. Cardiomyocytes were classified as ventricular-like if their APs showed a distinct "shoulder" (plateau or flat repolarization phase) prior to a final steep phase of repolarization. As a shoulder we classified cells that showed a depolarisation above $0 \mathrm{mV}$ for more than $100 \mathrm{~ms}$ and which exhibited a "clear" plateau, i.e. a time period of at least $50 \mathrm{~ms}$ in duration with less than an overall drop of $20 \mathrm{mV}$ in membrane potential. Although we have not determined the distribution of such ventricular-like APs among the entire population of patched cells, we estimate the percentage of ventricular-like cells to be at least $20 \%$.

\section{Electrophysiological solutions}

Solutions to record $\mathrm{K}^{+}$currents; pipette solution contained $130 \mathrm{mM} \mathrm{KCl}, 5 \mathrm{mM} \mathrm{MgCl} 2,5 \mathrm{mM} \mathrm{K2-ATP}$, $5 \mathrm{mM}$ EGTA, and $10 \mathrm{mM}$ HEPES (pH 5 7.2, KOH), and bath solution consisted of $137 \mathrm{mM} \mathrm{NaCl}, 4 \mathrm{mM} \mathrm{KCl}$, $1.8 \mathrm{mM} \mathrm{CaCl} 2,1 \mathrm{mM} \mathrm{MgCl}$, $10 \mathrm{mM}$ glucose, and $10 \mathrm{mM}$ HEPES (pH 5 7.4, NaOH). A pH of 6.8 and 8.2 was adjusted with $\mathrm{HCl}$ and $\mathrm{NaOH}$, respectively. Barium was used as charge carrier in experiments to measure $\mathrm{Ca}_{\mathrm{v}} 1.2$ calcium channels. Formulation of the recording solutions were as follows, pipette solution: $145 \mathrm{mM}$ Cs-aspartate, $2 \mathrm{mM} \mathrm{MgCl}$, $10 \mathrm{mM}$ HEPES, $0.1 \mathrm{mM}$ Cs-EGTA, $2 \mathrm{mM}$ Mg-ATP, pH = 7.4 adjusted with CsOH, and bath solution: $10 \mathrm{mM} \mathrm{BaCl} 2,145 \mathrm{mM}$ TEA-Cl, $10 \mathrm{mM}$ HEPES, $\mathrm{pH}=7.4$ adjusted with TEA-OH. To measure action potentials the pipette solution contained $10 \mathrm{mM} \mathrm{NaCl}, 140 \mathrm{mM} \mathrm{KCl}, 2 \mathrm{mM}$ EGTA, $1 \mathrm{mM} \mathrm{MgCl} 2,0.1$ mM Na-GTP, 5 mM Mg-ATP, $10 \mathrm{mM}$ Hepes, and pH = 7.2 adjusted with $\mathrm{KOH}$, while the cells were bathed in $140 \mathrm{mM} \mathrm{NaCl}, 4 \mathrm{mM} \mathrm{KCl}, 2 \mathrm{mM} \mathrm{CaCl} 2,2 \mathrm{mM}$ MgCl2, $5 \mathrm{mM}$ HEPES, $5 \mathrm{mM}$ glucose, and $\mathrm{pH}=7.4$ adjusted with $\mathrm{NaOH}$.

To measure sodium currents the pipette solution contained $105 \mathrm{mM} \mathrm{CsF}, 10 \mathrm{mM} \mathrm{NaCl}, 10 \mathrm{mM}$ EGTA, $10 \mathrm{mM}$ HEPES, $\mathrm{pH}=7.3$ adjusted with $\mathrm{CsOH}$. Recordings of hNav1.5 sodium channels expressed in tsA-201 cells were made in a bath solution that consisted of $140 \mathrm{mM} \mathrm{NaCl}, 2.5 \mathrm{mM} \mathrm{KCl}, 1 \mathrm{mM} \mathrm{CaCl} 2,1 \mathrm{mM} \mathrm{MgCl} 2,10$ mM HEPES, $\mathrm{pH}=7.4$ adjusted with $\mathrm{NaOH}$.

\section{Ivabradine}

Ivabradine was purchased from Sigma Aldrich (SML0281). The drug is the S-stereoisomer, (+)-S16257, of the parent racemate, (+-)-S15544. Ivabradine was dissolved in dimethyl sulfoxide at a stock concentration of $100 \mathrm{mM}$ and stored in aliquots at $-20^{\circ} \mathrm{C}$. All solutions were prepared freshly on the day of experiment by diluting the ivabradine stock to the respective concentrations as given within this study.

\section{Curve fitting}

Normalized concentration response relations were fit with a Hill equation: Inorm $=$ Bottom + (TopBottom $) /\left(1+\left(\mathrm{IC}_{50} /[\mathrm{iva}]\right)^{\wedge} \mathrm{n}_{\mathrm{H}}\right)$. Inorm is the normalised current during drug exposure in relation to the current during drug-free conditions, Bottom and Top refer to the minimal and maximal current level, $\mathrm{IC}_{50}$ is the concentration at $50 \%$ current inhibition, and [iva] is the concentration of ivabradine. The Hill slope $\mathrm{n}_{\mathrm{H}}$ was set to 1 , assuming a 1:1 binding stoichiometry.

\section{Results}

Ivabradine inhibits human $K_{v} 11.1$ channels at low $\mu M$ concentrations

Recently, inhibition of delayed rectifying potassium current $\mathrm{IK}_{\mathrm{r}}$ was reported in rabbit ventricular myocytes with low $\mu \mathrm{M}$ concentrations of ivabradine [10]; its molecular correlate, the ether-a-go-go-related gene channel (ERG, $\mathrm{K}_{\mathrm{v}} 11.1$ ), was inhibited with similar potency $[9,13]$. Within our aim to determine the effects of ivabradine on major human ventricular voltage-gated ion channels, we first repeated to test for the effect of ivabradine on human $\mathrm{K}_{\mathrm{v}} 11.1$ channels (Fig. 1). To this end we expressed human $\mathrm{K}_{\mathrm{v}} 11.1$ channels in tsA-201 cells. Potassium currents through these channels were activated from a holding potential of -80 $\mathrm{mV}$ by rectangular voltage steps and subsequently deactivated by a step to $-50 \mathrm{mV}$ (Fig. $1 \mathrm{a}$, b). The effect of ivabradine was then tested for different concentrations on the tail current 

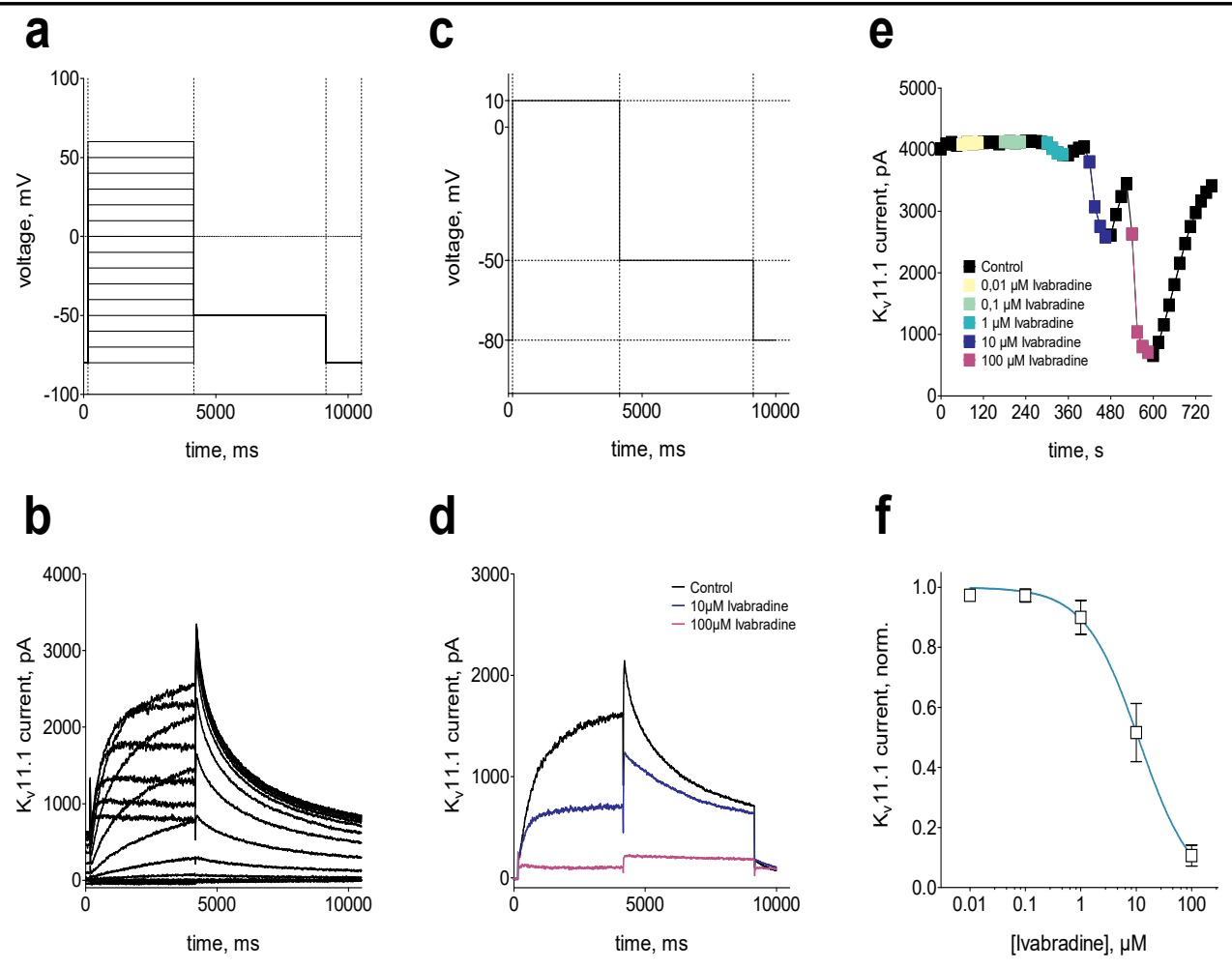

Fig. 1. Effect of ivabradine on heterologously expressed human $K_{v} 11.1$ channels. (a) Voltage-clamp protocol to derive current voltage relationships. (b) Typical outward potassium currents as elicited by the voltageclamp protocol shown in (a) for recombinant $\mathrm{K}_{\mathrm{v}} 11.1$ channels expressed in tsA-201 cells. (c) Two-step voltage-clamp protocol $(+10 \mathrm{mV},-50 \mathrm{mV})$ applied every $15 \mathrm{~s}$ to first activate and then deactivate $\mathrm{K}_{\mathrm{v}} 11.1$ channels. (d) Typical outward potassium currents for the voltage-clamp protocol shown in (c) under control conditions and in the presence of 10 and $100 \mu \mathrm{M}$ of ivabradine. The peak of tail currents at $-50 \mathrm{mV}$ was monitored to test for the effect of different ivabradine concentrations. (e) $\mathrm{K}_{\mathrm{v}} 11.1$ tail current amplitude as elicited by the voltage-clamp protocol in (c, d) under control conditions and in the presence of ascending concentrations of ivabradine. (f) Summary of normalized steady-state $\mathrm{K}_{\mathrm{v}} 11.1$ current amplitudes (mean +$\mathrm{SEM}, \mathrm{n}=7$ ) for all ivabradine concentrations tested. A Non-linear fit with a Hill equation (petrol) resulted in an $\mathrm{IC}_{50}$ value of $11+-2 \mu \mathrm{M}$.

amplitudes measured at $-50 \mathrm{mV}$ after maximal activation at $+10 \mathrm{mV}$ (Fig. 1c, d). Wash-in of ivabradine resulted in visible inhibition of the tail current for concentrations exceeding 0.1 $\mu \mathrm{M}$ and in a maximal inhibition at about $100 \mu \mathrm{M}$ (Fig. 1e). A summary of relative $\mathrm{K}_{\mathrm{v}} 11.1$ tail current inhibition for all tested ivabradine concentrations is shown in Fig. $1 \mathrm{f}$ and revealed an $\mathrm{IC}_{50}$ of $11+-2 \mu \mathrm{M}$. These results confirm previous findings in that ivabradine inhibits $\mathrm{K}_{\mathrm{v}} 11.1$ potassium current at low $\mu \mathrm{M}$ concentrations.

\section{Human $K_{v} 7.1$ channels are not affected by ivabradine}

Human ventricular repolarisation is dominated by the efflux of potassium through $\mathrm{K}_{\mathrm{v}} 11.1$ and $\mathrm{K}_{\mathrm{v}} 7.1$ channels, mediating the fast and slow rectifying potassium currents, $\mathrm{IK}_{\mathrm{r}}$ and $\mathrm{IK}_{\mathrm{s}}$, respectively. Having determined the effect of ivabradine on $\mathrm{K}_{\mathrm{v}} 11.1$, we next wanted to investigate the drug's effect on human $\mathrm{K}_{\mathrm{v}} 7.1$ channels. To this end we heterologously coexpressed the pore-forming KCNQ1 subunit together with KCNE1, mimicking the suggested in situ channel complex. A two step voltage-clamp protocol was used to activate $\mathrm{K}_{\mathrm{v}} 7.1$ channels and elicit respective potassium outward currents (Fig. 2a, b). The effect of ivabradine was tested on peak $\mathrm{K}_{\mathrm{v}} 7.1$ current amplitudes elicited at $+20 \mathrm{mV}$ (Fig. 2c, d). As can be seen from Fig. 2e, none of the employed ivabradine concentrations affected currents through $\mathrm{K}_{\mathrm{v}}$ 7.1. A 
summary of all recordings revelead no significant effect of $\mathrm{K}_{\mathrm{v}} 7.1$ up to $100 \mu \mathrm{M}$, the highest concentration tested.

\section{Partial inhibition of human Ca 1.2 calcium channels by ivabradine}

Previous reports $[9,13]$ and the results of the present work (Fig. 1) demonstrated substantial inhibition of $\mathrm{K}_{\mathrm{v}} 11.1$ by ivabradine at low $\mu \mathrm{M}$ concentrations. Inhibiton of $\mathrm{K}_{\mathrm{v}} 11.1$ channels is associated with a prolongation of the human ventricular AP and an increase of the QT interval in the ECG. However, in animal models no or only a very modest prolongation of the AP was observed when challenged with ivabradine concentrations of up to $10 \mu \mathrm{M}$ [911]. This prompted us to hypothesise that inhibition of calcium channels may compensate for the inhibition of $\mathrm{K}_{\mathrm{v}} 11.1$ and restore AP duration in the presence of ivabradine. In SA cells derived from rabbit hearts, ivabradine indeed inhibited L-type $\mathrm{Ca}^{2+}$ currents by about $20 \%$ at $10 \mu \mathrm{M}$ [3]. Therefore we asked if $\mathrm{Ca}_{\mathrm{v}} 1.2$, the predominant $\mathrm{Ca}^{2+}$-channel expressed in the human ventricle, would be affected by ivabradine.

To this end we co-expressed the pore forming alpha1C-subunit together with the auxiliary beta and alpha2delta-subunit heterologously in tsA-201 cells. Inward currents through these channels were activated by depolarising voltage-steps from a resting potential of $-80 \mathrm{mV}$ (Fig. 3a, b). To test for the effect of ivabradine, currents through $\mathrm{Ca}_{\mathrm{v}} 1.2$ channels

a

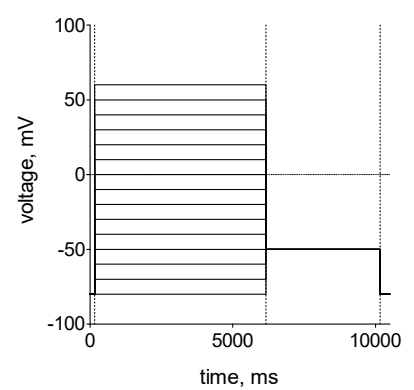

b

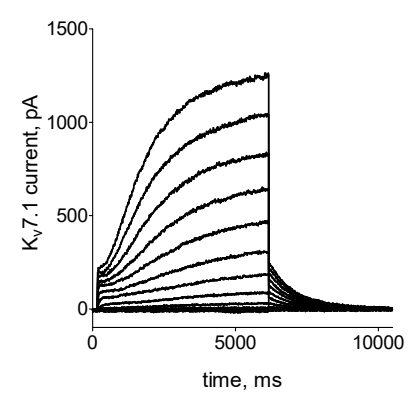

C

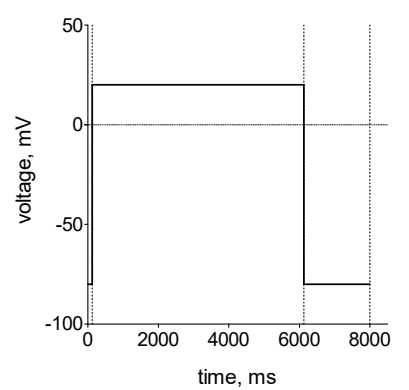

d

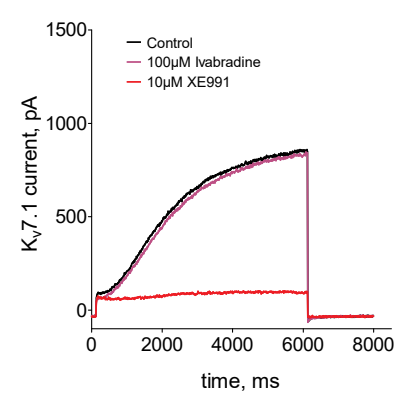

e

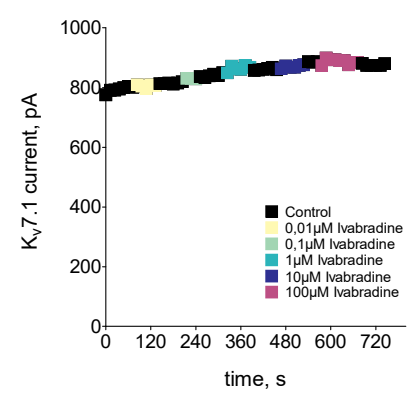

f

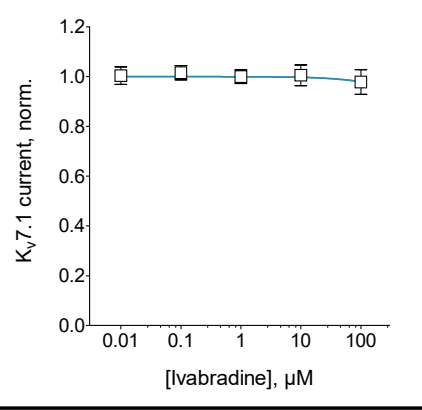

Fig. 2. Effect of ivabradine on heterologously expressed human $K_{v} 7.1$ channels. (a) Voltage-clamp protocol to derive current voltage relationships. (b) Typical outward potassium currents as elicited by the voltageclamp protocol shown in (a) for recombinant $\mathrm{K}_{\mathrm{v}} 7.1$ channels expressed in tsA-201 cells. (c) A voltage-step to $+20 \mathrm{mV}$ was applied every $12 \mathrm{~s}$ to activate $\mathrm{K}_{\mathrm{v}} 7.1$ channels. (d) Typical outward potassium currents for the voltage-clamp protocol shown in (c) under control conditions and in the presence of 10 and $100 \mu \mathrm{M}$ of ivabradine. The peak of $\mathrm{K}_{\mathrm{v}} 7.1$ current amplitude at the end of the $+20 \mathrm{mV}$ voltage-step was monitored to test for the effect of different ivabradine concentrations. A saturating concentration $(10 \mu \mathrm{M})$ of XE-991, a selective inhbitor of $\mathrm{K}_{\mathrm{v}} 7.1$ channels, was applied at the end in some experiments. (e) $\mathrm{K}_{\mathrm{v}} 7.1$ current amplitude as elicited by the voltage-clamp protocol in (c, d) under control conditions and in the presence of ascending concentrations of ivabradine. (f) Summary of normalized steady-state $\mathrm{K}_{\mathrm{v}} 7.1$ current amplitudes (mean +$\mathrm{SEM}, \mathrm{n}=7$ ) for all ivabradine concentrations tested. No significant current inhibitions was observed for ivabradine concentrations up to $100 \mu \mathrm{M}$. 


\section{a}

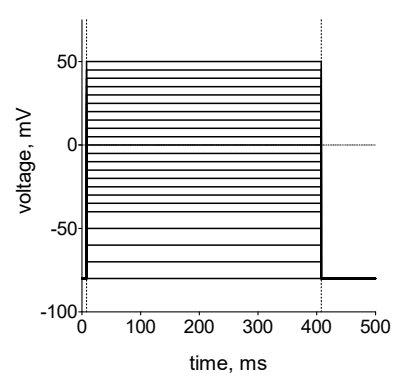

b

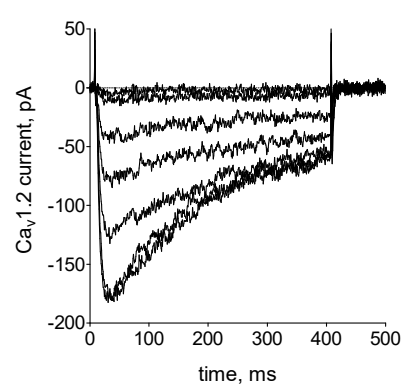

C

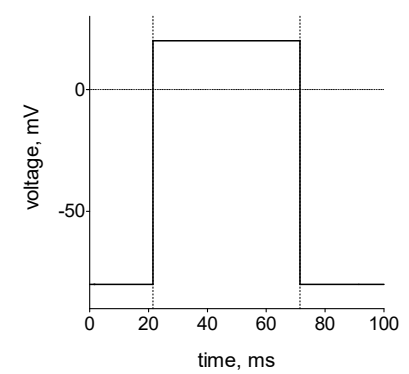

d

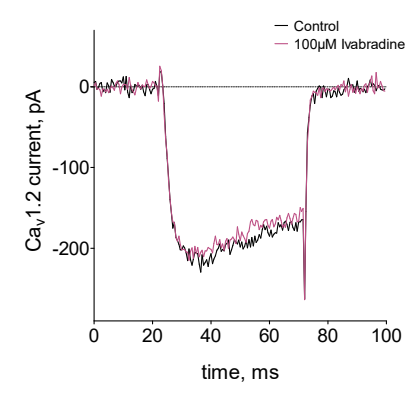

e

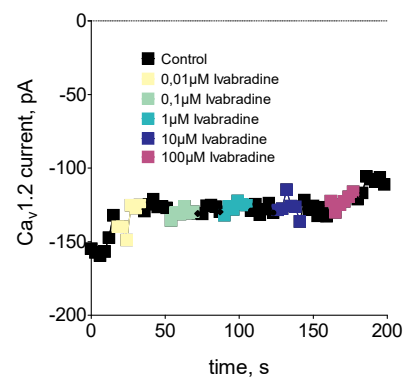

f

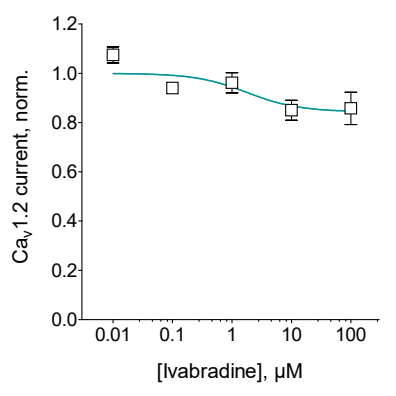

Fig. 3. Effect of ivabradine on heterologously expressed human $\mathrm{Ca}_{\mathrm{v}} 1.2$ channels. (a) Voltage-clamp protocol to derive current voltage relationships. (b) Typical inward currents through recombinant $\mathrm{Ca}_{\mathrm{v}} 1.2$ channels expressed in tsA-201 cells as elicited by the voltage-clamp protocol shown in (a) for selected voltage steps $(-25,-15,-5,0,5,10$, and $15 \mathrm{mV})$. Barium was used as charge carrier (see Methods). (c) Voltage clamp protocol to elicit maximal calcium current amplitude was applied every $3 \mathrm{~s}$. (d) Typical calcium current for the voltage-clamp protocol shown in (c) under control conditions and in the presence of $100 \mu \mathrm{M}$ of ivabradine. (e) Maximal $\mathrm{Ca}_{\mathrm{v}} 1.2$ current amplitude as elicited by the voltage-step to $+20 \mathrm{mV}$ (c, d) under control conditions and in the presence of ascending concentrations of ivabradine. (f) Summary of normalized steady-state $\mathrm{Ca}_{\mathrm{v}} 1.2$ current amplitudes (mean +- SEM, $\left.\mathrm{n}=13-15\right)$ for all ivabradine concentrations tested. A Non-linear fit with a Hill equation (line) was statistically not significant using and extra sum of square F-test.

were repetitively activated by a voltage-step to $+20 \mathrm{mV}$ (Fig. 3c, d). Only a trend of inhibition could be observed upon application of ivabradine (Fig. 3e, f), which, however, was not statistically significant. Thus, under our experimental conditions human $\mathrm{Ca}_{\mathrm{v}} 1.2$ calcium channels were not inhibited by ivabradine.

\section{Ivabradine inhibits human $\mathrm{Na}_{v} 1.5$ channels at low $\mu$ M concentrations}

Previous reports in dog Purkinje fibres and guinea pig ventricular papillary muscle found a decrease in $V_{\text {max }}$, the action potential upstroke velocity, upon application of ivabradine [10, 11]. We therefore wanted to test the effect of ivabradine on human $\mathrm{Na}_{\mathrm{v}} 1.5$ sodium channels.

Human $\mathrm{Na}_{\mathrm{v}} 1.5$ channels were heterologously expressed in tsA-201 cells. Sodium currents through these channels were activated from a holding potential of $-100 \mathrm{mV}$ by rectangular voltage-steps of $25 \mathrm{~ms}$ duration (Fig. 4a, b). To test for the effect of ivabradine, sodium currents were repetitively activated at a rate of $1 \mathrm{~Hz}$ by a $25 \mathrm{~ms}$ voltage-step to $-10 \mathrm{mV}$ (Fig. $4 c, d)$. Maximal current amplitude was monitored over time and ascending concentrations of ivabradine were applied for 2 minutes each (Fig. $4 \mathrm{e}$ ). $\mathrm{Na}_{\mathrm{v}} 1.5$ sodium currents were significantly inhibited by ivabradine. The half inhibitory conentration amounted to $\mathrm{IC}_{50}=30$ +- $3 \mu \mathrm{M}$ (mean +- SEM, $\mathrm{n}=3$-13; Fig. 4f). The observed ivabradine block was not affected by a potential systematic current rundown (Supplementary Fig. 1a), but washout of $100 \mu \mathrm{M}$ of the drug appeared slow and irreversible to some degree (Supplementary Fig. 1b-d - for all supplemental material see www.cellphysiolbiochem.com). 


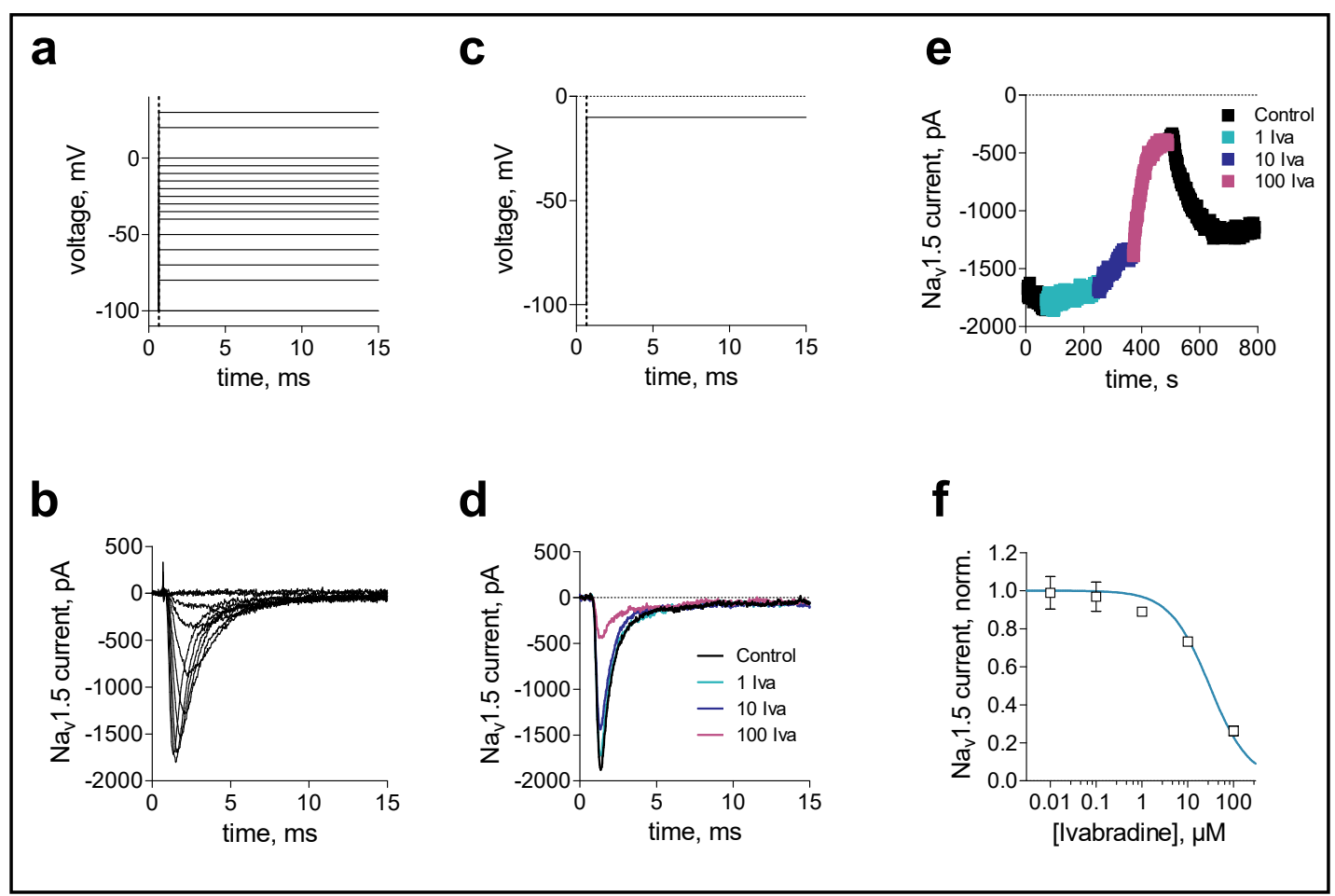

Fig. 4. Effect of ivabradine on heterologously expressed human $\mathrm{Na}_{\mathrm{v}} 1.5$ channels. (a) Voltage-clamp protocol to obtain current voltage relationships. (b) Typical inward currents through recombinant $\mathrm{Na}_{\mathrm{v}} 1.5$ channels expressed in tsA-201 cells as elicited by the voltage-clamp protocol shown in (a) for selected voltage steps $(-60,-50,-40,-35,-30,-25,-20,-15,-10$, and $0 \mathrm{mV})$. (c) Voltage clamp protocol to elicit maximal sodium current amplitude. (d) Typical sodium current for the voltage-clamp protocol shown in (c) under control conditions and in the presence of 1,10 , and $100 \mu \mathrm{M}$ of ivabradine. (e) Maximal $\mathrm{Na}_{\mathrm{v}} 1.5$ current amplitude as elicited repetitively at $1 \mathrm{~Hz}$ by a voltage-step to $-10 \mathrm{mV}$ as shown in (c, d) under control conditions and in the presence of ivabradine. (f) Summary of normalized steady-state $\mathrm{Na}_{\mathrm{v}} 1.5$ current amplitudes for all ivabradine concentrations tested. The line represents a non-linear fit with a Hill equation.

\section{Ivabradine does not prolong the human cardiac action potential}

Recent studies reported no or only very minor changes in the AP duration upon application of ivabradine in various animal models [9-11], in a human right ventricular papillary muscle preparation [10], and in human induced pluripotent stem cells (iPSC)derived engineered heart tissue [28].

Here we wanted to test the synergistic effect of sodium, calcium and potassium channel inhibition on a human model of the cardiac AP. To this end we used single cardiomyocytes derived from iPSCs. Action potentials were elicited by a 4 ms current injection at a rate of $1 \mathrm{~Hz}$. Only cells with 'ventricular-like' APs were selected for experiments. After the AP had stabilized ivabradine was applied at concentrations of 1 and $10 \mu \mathrm{M}$ for 1 min each (Fig. 5a). No change in action potential duration measured at $90 \%$ repolarization was observed (APD90, Fig. $5 b$ ). However, in accordance with the inhibition of Nav1.5 by ivabradine, we observed a reduction in the AP depolarisation level (Fig. 5c) and a slowing of the AP upstroke velocity (Fig. 5d). 
Fig. 5. Effect of ivabradine on human APs from iPSC derived cardiomyocytes. Example of ventricularlike action potentials as obtained from current clamp measurements in iPS cell derived human cardiomyocytes under control conditions and after 1 minute equilibration with either 1 or $10 \mu \mathrm{M}$ of ivabradine (1 Iva, and 10 Iva, respectively). (b) A summary of the AP duration measured at $90 \%$ repolarisation (APD90) as derived from experiments shown in (a). (c) Summary of the maximal depolarisation value reached by the AP. (d) Summary of the maximal upstroke velocity as derived by taking the maximum of the first time derivative, max $\mathrm{dV} / \mathrm{dt}$. All data are displayed as mean +- SEM ( $\mathrm{n}=8$ and 7, for 1 and 10 Iva, respectively). Statistical significance for 1 and 10 Iva versus control was tested with a paired Student's t-test; ns, not significant.

\section{Discussion}

Within the present work we show significant inhibitory action of ivabradine on human cardiac ion channels other than HCN. We could confirm recent findings of the inhibition of human $\mathrm{K}_{\mathrm{v}} 11.1$ (hERG) channels by low $\mu \mathrm{M}$ concentrations of ivabradine (Fig. 1). In order to find an explanation for the fact that, despite inhibition of $\mathrm{K}_{\mathrm{v}} 11.1$ channels, AP duration is not affected, we investigated $\mathrm{K}_{\mathrm{v}} 7.1$ channels, which constitute the second major potassium conductance driving late ventricular repolarisation. By showing that ivabradine, even at high $\mu \mathrm{M}$ concentrations, had no effect on $\mathrm{K}_{\mathrm{v}} 7.1$ (Fig. 2), we could rule out the possibility that a potentiation of these channels counteract the inhibition of $\mathrm{K}_{\mathrm{v}} 11.1$ channels. Next, we surmised that depolarising sodium and/or calcium currents could represent the soughtafter compensatory mechanism. For human $\mathrm{Ca}_{\mathrm{v}} 1.2$ calcium channels we found a trend of inhibition by ivabradine which, however, was not statistically significant (Fig. 3). No, or only a small effect of ivabradine, on voltage-gated calcium channels is consistent with previous findings in SA cells derived from rabbit hearts [3]. More importantly, however, when we next investigated the effect of ivabradine on human $\mathrm{Na}_{\mathrm{v}} 1.5$ voltage-gated sodium channels, we found that these channels are considerably inhibited at low $\mu \mathrm{M}$ concentrations (Fig. 4).

We determined an $\mathrm{IC}_{50}$ value of $30 \mu \mathrm{M}$ for the inhibition of human $\mathrm{Na}_{\mathrm{v}} 1.5$ by ivabradine under our experimental conditions. This is an order of magnitude higher than the $\mathrm{IC}_{50}$ values reported for HCN channel inhibition [5, 29]. There are, however, a few points that need to be considered. First, sodium currents measured within this study were elicited by voltage-steps of relatively brief duration ( $25 \mathrm{~ms}$ ), while during the rest of the protocol time voltage was clamped at $-100 \mathrm{mV}$. Under these conditions, most channels are in the closed state for the 
predominant time and open and inactivate only briefly during the time of depolarisation. The employed protocol thus favours open-channel block and leaves only very limited time for a binding of inactivated channel states. The human AP, which is an order of magnitude longer, would allow significantly more channels to enter the inactivated states. Taking into account that classical sodium channel inhibitors from the group of local anaesthetics, e.g. lidocaine, preferentially target the inactivated states $[30,31]$, it is reasonable to assume that this is also true for ivabradine. Second, our measurements were performed at room temperature for which channel gating and drug equilibration occurs at a much slower rate compared to physiological temperatures of $37^{\circ} \mathrm{C}$. Third, we did not study the rate-dependence or voltage-dependence of sodium channel inhibition by ivabradine. Here we only report the $\mathrm{IC}_{50}$ value for a voltage-clamp protocol consisting of $25 \mathrm{~ms}$ voltage steps to $-10 \mathrm{mV}$ applied at a rate of $1 \mathrm{~Hz}$. The inherent voltage-dependence of a drug that supposedly binds in a statedependent manner together with the fact that ivabradine is estimated to be $99 \%$ charged at physiological $\mathrm{pH}$ (tertiary amine with a $\mathrm{pK}_{\mathrm{a}}$ of 9.4), would suggest a strong influence of membrane voltage on the observed IC $_{50}$ value. Thus, our reported IC $_{50}$ value should be seen as an upper estimate for $\mathrm{Na}_{\mathrm{v}} 1.5$ inhibition under more physiological conditions. Clearly, future studies should investigate the state-dependence, temperature-dependence and usedependence of $\mathrm{Na}_{\mathrm{v}} 1.5$ inhibition by ivabradine in order to gain a better understanding of the physiological consequences associated with this finding.

Previous work has identified a slowing of AV conduction upon application of the $I_{f}$ inhibitor zatebradine. Application of the drug induced a prolongation of the atrial-His bundle (AH) interval in a canine model of disrupted sinoatrial node function [32]. Recently, a similar finding was observed with ivabradine: slowed AV-node conduction in a guinea pig model [15]. The authors claimed that HCN channels, in particular HCN4, are expressed in AV tissue, and that inhibition of these channels would slow AV conduction. Our results provide the basis for an alternative interpretation. The inhibition of sodium channels, eventually in synergy with a small reduction in calcium current, could equally likely be responsible for the observed reduction in AV conduction speed.

There are several arguments that support the notion that sodium channel block may contribute to the ivabradine-induced suppression of conduction through the AV-node. First, $\mathrm{Na}_{v} 1.5$ channels are expressed in the human AV-node, although to a lesser degree than in atrial and ventricular muscle [33]. Human channelopathies due to loss-of-function mutations in voltage-gated sodium channels are associated with prolonged conduction through the AVnode (for review see [34]). This phenotype is also reproduced in respective murine models of human cardiac conduction diseases (e.g. [35]). Increased AV-nodal conduction times have been reported after administration of the $\mathrm{Na}^{+}$channel blockers lidocaine and flecainide [3638], and AV-block has been reported in patients treated with sodium channel blockers [39, 40]. In isolated guinea pig hearts ivabradine produced a strong rate-dependent prolongation of the AH-interval consistent with a drug-induced prolongation of AV-nodal conduction [15]. Interestingly, although the authors concluded that the HV-interval remained unchanged by ivabradine, close inspection of their original Fig. $6 \mathrm{~B}$ (in [15]) strongly suggests a $\sim 20 \%$ increase of the HV interval at a cycle length of $160 \mathrm{~ms}$ by $3 \mu \mathrm{M}$ ivabradine. On the other hand, the same authors did not observe any effect of $0.1 \mathrm{mg} / \mathrm{kg}$ iv. ivabradine in the intact porcine heart at a cycle length of $333 \mathrm{~ms}$. These changes may reflect a highly rate-dependent $\mathrm{Na}^{+}$channel block by ivabradine. Interestingly, voltage-gated sodium channels are involved in the pacemaker function of the sinus node $[41,42]$. Hence, the sodium channel blocking activity of ivabradine may also contribute to its bradycardic action.

On the other hand a slowing of AV-nodal conduction has also been observed in a murine model of inducible cardiac-specific knockout of the pacemaker channel gene Hcn4 [43] implying that HCN channels themselves may be involved in signal conduction through the AV node. This notion is supported by in-silico studies using a theoretical model of AV-nodal conduction $[22,23]$. Hence, both block of HCN channels and block of voltage-gated sodium channels may contribute to slowing of conduction through the AV node by ivabradine. 


\section{Cellular Physiology Cell Physiol Biochem 2019;53:36-48 \begin{tabular}{c|c|c|c|c|} 
Dol: 10.33594/000000119 & O 2019 The Author(s). Published by \\
and Biochemistry Published online: 7 lune 2019 & Cell Physel
\end{tabular} \\ Hächl et al.: Ivabradine Effects on Human Cardiac Ion Channels}

The present work presents a potential explanation why ivabradine despite its affinity for $\mathrm{K}_{\mathrm{v}} 11.1$ (hERG) potassium channels does not lead to a prolongation of the cardiac AP and concomitant increase of the $\mathrm{QT}_{\mathrm{c}}$ interval in human ECG recordings. Furthermore, our results provide an alternative explanation for the recent observations of increased atrial-His bundle intervals and thus slowed atrial-ventricular conduction upon administration of ivabradine [15].

Finally, the possibility of $\mathrm{Na}_{\mathrm{v}} 1.5$ channel inhibition at clinically relevant ivabradine concentrations clearly demands further investigations.

\section{Acknowledgements}

The authors are very grateful for the excellent work of Jarmila Uhrinova. This work was funded by the "Österreichische Muskelforschung" (ÖMF) supported by the "Harley Davidson Charity Fonds" (AP008450FF/KP008450FF to Xaver Koenig). Data acquisition: N.H., J. E., X.K.; Data evaluation: N.H., J. E., X.K.; Design of the study: X.K., H.T.; Writing of the manuscript: K.H., H.T., X.K.

\section{Disclosure Statement}

The authors have no conflicts of interest to declare.

\section{References}

1 Ciccone M, Scicchitano P, Cortese F, Ricci G, Carbonara S, Moncelli M, Iacoviello M, Cecere A, Gesualdo M, Zito A, Caldarola P, Scrutinio D, Lagioia R, Riccioni G, Ciccone MM: Ivabradine, coronary artery disease, and heart failure: beyond rhythm control. Drug Des Devel Ther 2014;8:689-700.

2 Rushworth GF, Lambrakis P, Leslie SJ: Ivabradine: A new rate-limiting therapy for coronary artery disease and heart failure. Ther Adv Drug Saf 2011;2:19-28.

3 Bois P, Bescond J, Renaudon B, Lenfant J: Mode of action of bradycardic agent, S 16257, on ionic currents of rabbit sinoatrial node cells. Br J Pharmacol 1996;118:1051-1057.

4 Bucchi A, Baruscotti M, DiFrancesco D: Current-dependent Block of Rabbit Sino-Atrial Node I f Channels by Ivabradine. J Gen Physiol 2002;120:1-13.

5 Bucchi A, Tognati A, Milanesi R, Baruscotti M, DiFrancesco D: Properties of ivabradine-induced block of HCN1 and HCN4 pacemaker channels. J Physiol 2006;572:335-346.

6 Savelieva I, Camm AJ: Novel I f Current Inhibitor Ivabradine: Safety Considerations, in Camm JA, Tendera M (eds): Heart Rate Slowing by I f Current Inhibition. Adv Cardiol 2006;43:79-96.

$7 \quad$ Koruth JS, Lala A, Pinney S, Reddy VY, Dukkipati SR: The Clinical Use of Ivabradine. J Am Coll Cardiol 2017;70:1777-1784.

8 Hancox JC, Melgari D, Dempsey CE, Brack KE, Mitcheson J, Ng GA: hERG potassium channel inhibition by ivabradine may contribute to QT prolongation and risk of torsades de pointes. Ther Adv Drug Saf 2015;6:177-179.

9 Melgari D, Brack KE, Zhang C, Zhang Y, Harchi A El, Mitcheson JS, Dempsey CE, Ng GA, Hancox JC: hERG potassium channel blockade by the HCN channel inhibitor bradycardic agent ivabradine. J Am Heart Assoc 2015;4:pii:e001813.

10 Koncz I, Szél T, Bitay M, Cerbai E, Jaeger K, Fülöp F, Jost N, Virág L, Orvos P, Tálosi L, Kristóf A, Baczkó I, Papp JG, Varró A: Electrophysiological effects of ivabradine in dog and human cardiac preparations: Potential antiarrhythmic actions. Eur J Pharmacol 2011;668:419-426.

11 Pérez O, Gay P, Franqueza L, Carron R, Valenzuela C, Delpon E, Tamargo J: Effects of the two enantiomers, S-16257-2 and S-16260-2, of a new bradycardic agent on guinea-pig isolated cardiac preparations. Br J Pharmacol 1995;115:787-794. 
12 Camm AJ, Lau CP: Electrophysiological effects of a single intravenous administration of ivabradine (S 16257) in adult patients with normal baseline electrophysiology. Drugs R D 2003;4:83-89.

13 Lees-Miller JP, Guo J, Wang Y, Perissinotti LL, Noskov SY, Duff HJ: Ivabradine prolongs phase 3 of cardiac repolarization and blocks the hERG1 $(\mathrm{KCNH} 2)$ current over a concentration-range overlapping with that required to block HCN4. J Mol Cell Cardiol 2015;85:71-78.

14 Viskin S, Rosovski U: The degree of potassium channel blockade and the risk of torsade de pointes: The truth, nothing but the truth, but not the whole truth. Eur Heart J 2005;26:536-537.

15 Verrier RL, Bonatti R, Silva AFG, Batatinha JAP, Nearing BD, Liu G, Rajamani S, Zeng D, Belardinelli L: If inhibition in the atrioventricular node by ivabradine causes rate-dependent slowing of conduction and reduces ventricular rate during atrial fibrillation. Hear Rhythm 2014;11:2288-2296.

16 Verrier RL, Silva AFG, Bonatti R, Batatinha JAP, Nearing BD, Liu G, Rajamani S, Zeng D, Belardinelli L: Combined actions of ivabradine and ranolazine reduce ventricular rate during atrial fibrillation. J Cardiovasc Electrophysiol 2015;26:329-335.

17 Caminiti G, Fossati C, Rosano G, Volterrani M: Addition of ivabradine to betablockers in patients with atrial fibrillation: Effects on heart rate and exercise tolerance. Int J Cardiol 2015;202:73-74.

18 Wongcharoen W, Ruttanaphol A, Gunaparn S, Phrommintikul A: Ivabradine reduced ventricular rate in patients with non-paroxysmal atrial fibrillation. Int J Cardiol 2016;224:252-255.

19 Turley SL, Francis KE, Lowe DK, Cahoon WD: Emerging role of ivabradine for rate control in atrial fibrillation. Ther Adv Cardiovasc Dis 2016;10:348-352.

20 Fontenla A, Villagraz L, de Juan J, Lozano Á, Giacoman S, López-Gil M: Ivabradine as an Alternative to AV Node Ablation in a Patient With Permanent Atrial Fibrillation. Rev Esp Cardiol 2017;70:1019-1020.

21 Koenig SN, Mohler PJ: Potential use of ivabradine for treatment of atrial fibrillation. J Cardiovasc Electrophysiol 2019;30:253-254.

$22 \mathrm{Li} \mathrm{J}$, Temple IP, Boyett MR: Theoretical Study of the Role of the Funny Current (If) and the Background Inward Current (Ib) in Atrioventricular Nodal Conduction. Comput Cardiol;41:865-868.

23 Li J, Mesirca P, D’Souza A, Wang Y, Nakao S, Cox C, Hancox J, Mangoni M, Boyett M: Heart Block in the Athlete - Role of Ion Channel Remodelling as Studied Using a One-Dimensional Computational Model of the Atrioventricular Node. Comput Cardiol 2019; DOI:10.22489/cinc.2018.285.

24 Chiamvimonvat V, Newman D, Tang A, Green M, Mitchell J, Wulffhart Z, Dorian P: A double-blind placebocontrolled evaluation of the human electrophysiologic effects of zatebradine, a sinus node inhibitor. J Cardiovasc Pharmacol 1998;32:516-520.

25 Koenig X, Kovar M, Rubi L, Mike AK, Lukacs P, Gawali VS, Todt H, Hilber K, Sandtner W: Anti-addiction drug ibogaine inhibits voltage-gated ionic currents: A study to assess the drug's cardiac ion channel profile. Toxicol Appl Pharmacol 2013;273:259-268.

26 Salzer I, Erdem FA, Chen WQ Heo S, Koenig X, Schicker KW, Kubista H, Lubec G, Boehm S, Yang JW: Phosphorylation regulates the sensitivity of voltage-gated Kv7.2 channels towards phosphatidylinositol-4, 5-bisphosphate. J Physiol 2017;595:759-776.

27 Rubi L, Eckert D, Boehm S, Hilber K, Koenig X: Anti-addiction Drug Ibogaine Prolongs the Action Potential in Human Induced Pluripotent Stem Cell-Derived Cardiomyocytes. Cardiovasc Toxicol 2017;17:215-218.

28 Lemoine MD, Krause T, Koivumäki JT, Prondzynski M, Schulze ML, Girdauskas E, Willems S, Hansen A, Eschenhagen T, Christ T: Human Induced Pluripotent Stem Cell-Derived Engineered Heart Tissue as a Sensitive Test System for QT Prolongation and Arrhythmic Triggers. Circ Arrhythmia Electrophysiol 2018;11:e006035.

29 Bucchi A, Baruscotti M, Nardini M, Barbuti A, Micheloni S, Bolognesi M, DiFrancesco D: Identification of the Molecular Site of Ivabradine Binding to HCN4 Channels. PLoS One 2013;8:1-12.

30 Sandtner W, Szendroedi J, Zarrabi T, Zebedin E, Hilber K, Glaaser I, Fozzard HA, Dudley SC, Todt H.: Lidocaine: A Foot in the Door of the Inner Vestibule Prevents Ultra-Slow Inactivation of a Voltage-Gated Sodium Channel. Mol Pharmacol 2004;66:648-657.

31 Gawali VS, Lukacs P, Cervenka R, Koenig X, Rubi L, Hilber K, Sandtner W, Todt H: Mechanism of Modification, by Lidocaine, of Fast and Slow Recovery from Inactivation of Voltage-Gated Na+ Channels. Mol Pharmacol 2015;88:866-879.

32 Yamazaki K, Furukawa Y, Nakano H, Kasama M, Imamura H, Chiba S: Inhibition of the subsidiary pacemaker activity by zatebradine, an Ifinhibitor, in the anesthetized dog heart. J Cardiovasc Pharmacol 1995;26:957-964. 


\section{Cellular Physiology Cell Physiol Biochem 2019;53:36-48

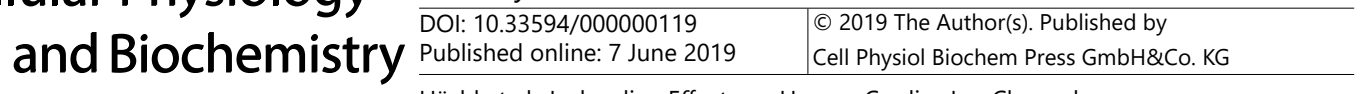 \\ Hächl et al.: Ivabradine Effects on Human Cardiac lon Channels}

33 Greener ID, Monfredi O, Inada S, Chandler NJ, Tellez JO, Atkinson A, Taube MA, Billeter R, Anderson RH, Efimov IR, Molenaar P, Sigg DC, Sharma V, Boyett MR, Dobrzynski H: Molecular architecture of the human specialised atrioventricular conduction axis. J Mol Cell Cardiol 2011;50:642-651.

34 Milanesi R, Bucchi A, Baruscotti M: The genetic basis for inherited forms of sinoatrial dysfunction and atrioventricular node dysfunction. J Interv Card Electrophysiol 2015;43:121-134.

35 Papadatos GA, Wallerstein PMR, Head CEG, Ratcliff R, Brady PA, Benndorf K, Benndorf K, Saumarez RC, Trezise AE, Huang CL, Vandenberg JI, Colledge WH, Grace AA: Slowed conduction and ventricular tachycardia after targeted disruption of the cardiac sodium channel gene Scn5a. Proc Natl Acad Sci 2002;99:6210-6215.

36 Lieberman NA, Harris RS, Katz RI, Lipschutz HM, Dolgin M, Fisher VJ: The effects of lidocaine on the electrical and mechanical activity of the heart. Am J Cardiol 1968;22:375-380.

37 Estes NAM, Garan H, Ruskin JN: Electrophysiologic properties of flecainide acetate. Am J Cardiol 1984;53:26B-29B.

38 Hellestrand KJ, Bexton RS, Nathan AW, Spurrell RA, Camm AJ: Acute electrophysiological effects of flecainide acetate on cardiac conduction and refractoriness in man. Heart 2007;48:140-148.

39 Lichstein E, Chadda KD, Gupta PK: Atrioventricular block with lidocaine therapy. Am J Cardiol 1973;31:277-281.

40 Grenadier E, Alpan G, Keidar S, Palant A: Atrio-ventricular block after administration of lignocaine in patients treated with prenylamine. Postgrad Med J 1982;58:175-177.

41 Marger L, Mesirca P, Alig J, Torrente A, Dubel S, Engeland B, Kanani S, Fontanaud P, Striessnig J, Shin HS, Isbrandt D, Ehmke H, Nargeot J, Mangoni ME: Pacemaker activity and ionic currents in mouse atrioventricular node cells. Channels 2011;5:241-250.

42 Lei M, Jones SA, Liu J, Lancaster MK, Fung SS-M, Dobrzynski H, Camelliti P, Maier SK, Noble D, Boyett MR: Requirement of neuronal- and cardiac-type sodium channels for murine sinoatrial node pacemaking. J Physiol 2004;559:835-848.

43 Baruscotti M, Bucchi A, Viscomi C, Mandelli G, Consalez G, Gnecchi-Rusconi T, Montano N, Casali KR, Micheloni S, Barbuti A, DiFrancesco D: Deep bradycardia and heart block caused by inducible cardiacspecific knockout of the pacemaker channel gene Hcn4. Proc Natl Acad Sci 2011;108:1705-1710. 